\title{
Enhancement of the Anabolic Effects of Growth Hormone and Insulin-like Growth Factor I by Use of Both Agents Simultaneously
}

\author{
Stuart R. Kupfer, ${ }^{*}$ Louis E. Underwood, ${ }^{*}$ Robert C. Baxter, ${ }^{*}$ and David R. Clemmons ${ }^{5}$ \\ Departments of ${ }^{*}$ Pediatrics and ${ }^{\S}$ Medicine, University of North Carolina School of Medicine, Chapel Hill, North Carolina 27599; \\ and ${ }^{\ddagger}$ Department of Endocrinology, Royal Prince Alfred Hospital, Camperdown, NSW 2050, Australia
}

\begin{abstract}
The use of growth hormone (GH) as an anabolic agent is limited by its tendency to cause hyperglycemia and by its inability to reverse nitrogen wasting in some catabolic conditions. In a previous study comparing the anabolic actions of GH and IGFI (insulin-like growth factor I), we observed that intravenous infusions of IGF-I (12 $\mu \mathrm{g} / \mathrm{kg}$ ideal body wt [IBW]/h) attenuated nitrogen wasting to a degree comparable to $\mathrm{GH}$ given subcutaneously at a standard dose of $0.05 \mathrm{mg} / \mathrm{kg}$ IBW per $\mathrm{d}$. IGF-I, however, had a tendency to cause hypoglycemia.

In the present study, we treated seven calorically restricted ( $20 \mathrm{kcal} / \mathrm{kg}$ IBW per d) normal volunteers with a combination of GH and IGF-I (using the same doses as in the previous study) and compared its effects on anabolism and carbohydrate metabolism to treatment with IGF-I alone. The GH/IGF-I combination caused significantly greater nitrogen retention (262 $\pm 43 \mathrm{mmol} / \mathrm{d}$, mean \pm SD) compared to IGF-I alone $(108 \pm 29 \mathrm{mmol} / \mathrm{d} ; \boldsymbol{P}<0.001)$. GH $/$ IGF-I treatment resulted in substantial urinary potassium conservation $(34 \pm 3 \mathrm{mmol} / \mathrm{d}$, mean \pm SE; $P<0.001$ ), suggesting that most protein accretion occurred in muscle and connective tissue. GH attenuated the hypoglycemia induced by IGF-I as indicated by fewer hypoglycemic episodes and higher capillary blood glucose concentrations on GH/IGF-I (4.3 $\pm 1.0 \mathrm{mmol} / \mathrm{liter}$, mean \pm SD) compared to IGF-I alone $(3.8 \pm 0.8 \mathrm{mmol} / \mathrm{liter} ; P<0.001)$. IGF-I caused a marked decline in C-peptide (1,165 $\pm 341 \mathrm{pmol} /$ liter; mean \pm SD) compared to the GH/IGF-I combination (2,280 $\pm 612 \mathrm{pmol} /$ liter; $P<0.001)$, suggesting maintenance of normal carbohydrate metabolism with the latter regimen. GH/IGF-I produced higher serum IGF-I concentrations $(1,854 \pm 708 \mu \mathrm{g} /$ liter; mean \pm SD) compared to IGF-I only treatment $(1,092 \pm 503 \mu \mathrm{g} /$ liter; $P<0.001)$. This observation was associated with increased concentrations of IGF binding protein 3 and acid-labile subunit on GH/IGF-I treatment and decreased concentrations on IGF-I alone.

These results suggest that the combination of GH and IGFI treatment is substantially more anabolic than either IGF-I or GH alone. GH / IGF-I treatment also attenuates the hypoglycemia caused by IGF-I alone. GH/IGF-I treatment could have
\end{abstract}

Address correspondence and reprint requests to Stuart R. Kupfer, M.D., Division of Pediatric Endocrinology, Department of Pediatrics, CB\#7220, 509 Burnett-Womack, University of North Carolina School of Medicine, Chapel Hill, NC 27599-7220.

Received for publication 19 June 1992 and in revised form 18 September 1992.

J. Clin. Invest.

(C) The American Society for Clinical Investigation, Inc. $0021-9738 / 93 / 02 / 0391 / 06 \quad \$ 2.00$

Volume 91, February 1993, 391-396 important applications in diseases associated with catabolism. (J. Clin. Invest. 1993. 91:391-396.) Key words: growth hormone $\bullet$ insulin-like growth factor I • anabolism • insulin • glucose regulation

\section{Introduction}

Patients with acute or chronic illnesses are often in negative nitrogen balance despite adequate nutritional support (1-3). Growth hormone $(\mathrm{GH})^{1}$ can cause a partial reversal of nitrogen wasting in humans who are catabolic because of surgery (4), glucocorticoid treatment (5), chronic obstructive pulmonary disease $(6)$, or dietary restriction $(7,8)$. However, $\mathrm{GH}$ has failed to improve nitrogen retention in some patients with sepsis (9) or burn injury (10). Furthermore, GH's tendency to cause insulin resistance (11) worsens the glucose intolerance associated with glucocorticoid therapy (5) or severe stress, such as that caused by extensive surface burns (10).

Insulin-like growth factor-I (IGF-I), a peptide that mediates the growth-promoting effects of $\mathrm{GH}(12,13)$, has been shown to reverse the catabolic effects of caloric restriction in normal volunteers (14). In a study comparing the anabolic actions of GH with IGF-I (14), we observed that infusions of IGF-I ( $12 \mu \mathrm{g} / \mathrm{kg}$ per $\mathrm{h}$ ) attenuate nitrogen wasting to a degree comparable to a standard treatment dose of $\mathrm{GH}(0.05 \mathrm{mg} / \mathrm{kg}$ per d). IGF-I infusion, however, had a tendency to cause hypoglycemia despite substantial suppression of insulin. In contrast, GH caused significant increases in both insulin and glucose concentrations, consistent with an increase in insulin resistance.

Based on these observations, we hypothesized that treatment with a combination of GH and IGF-I would ameliorate the hypoglycemia caused by IGF-I given alone, and that combined GH/IGF-I treatment would be more anabolic than either hormone given alone. Therefore, we treated calorically restricted normal volunteers with a combination of $\mathrm{GH}$ and IGF-I, and compared its effects to IGF-I alone.

\section{Methods}

Study design. The seven normal volunteers (four men and three women, ages $22-47 \mathrm{yr}$ ) who participated in this study were recruited by advertisement and were within $10 \%$ of ideal body weight (15). They were determined to be in good health by medical history, physical examination, and routine laboratory studies (complete blood count, electrolytes, urea nitrogen, creatinine, uric acid, total protein, albumin, total bilirubin, glucose, calcium, phosphorus, hepatic enzymes, lipid

1. Abbreviations used in this paper: ALS, acid-labile subunit of the 150-kD insulin-like growth factor binding protein complex; $\mathrm{GH}$, growth hormone; IBW, ideal body weight; IGF-I, insulin-line growth factor I; IGFBP, IGF binding protein. 
profile, and urinalysis). The study was approved by the University of North Carolina Institutional Committee for the Protection of the Rights of Human Subjects, and informed consent was obtained from each subject. The subjects were monitored on the General Clinical Research Center of the University of North Carolina (Chapel Hill, NC).

Subjects were permitted to continue most of their daily activities outside the hospital but were asked to refrain from vigorous exercise. During each of the two 2-wk diet periods, the subjects reported to the General Clinical Research Center daily for weighing, blood drawing, submission of 24-h urine collections, and consumption of meals. During weeks 1 and 2 of the study, each subject was fed a diet containing 20 $\mathrm{kcal} / \mathrm{kg}$ IBW with $1 \mathrm{~g}$ protein $/ \mathrm{kg}$ IBW. Nonprotein calories were provided as $50 \%$ carbohydrate and $50 \%$ lipid. The diet included $5 \mathrm{kcal} / \mathrm{kg}$ per $\mathrm{d}$ of carbohydrate in the form of juice divided into three aliquots and given at the hours of 0600,2000 , and 2400 each day. The nutrient content of the weighed food in each diet was determined from United States Department of Agriculture food tables (16). Dietary compliance was monitored by weighing the food left after each meal and by observing the constancy of weight loss and urinary nitrogen excretion.

During the last $4 \mathrm{~d}$ of week 1 and each day of week 2, 24-h urines were collected for urea nitrogen, creatinine, and potassium. During this same interval morning blood samples were collected before breakfast $(0700 \mathrm{~h})$ for glucose, urea nitrogen, electrolytes, creatinine, insulin, C-peptide, IGF-I, IGF binding proteins (IGFBP) 1, 2, and 3 and the acid-labile subunit (ALS) of the $150-\mathrm{kD}$ IGF binding protein complex. On day 4 of week 2, blood samples were collected at $0700,1600,1800$, 2000 , and $2400 \mathrm{~h}$ to assess the pharmacokinetics of IGF-I. During week 2 , subjects received one of two treatments: $(a)$ daily intravenous infusions of recombinant human IGF-I (gift from Genentech, Inc., South San Francisco, CA) at a dose of $12 \mu \mathrm{g} / \mathrm{kg}$ IBW per $\mathrm{h}$ for $16 \mathrm{~h}$ between the hours of 1600 and 0800 for $5 \mathrm{~d}$; or $(b)$ combination of IGF-I (same conditions as above) and daily subcutaneous injections of recombinant human GH (Nutropin ${ }^{\star}$, gift from Genentech, Inc.) at a dose of 0.05 $\mathrm{mg} / \mathrm{kg}$ IBW that was given at $1600 \mathrm{~h}$ for $5 \mathrm{~d}$. On the sixth day, the IGF-I infusion was given between 0800 and $2400 \mathrm{~h}$, and the GH was administered at 0800 . At times, the IGF-I infusion rate had to be reduced temporarily because of hypoglycemia (e.g., blood glucose $<55$ $\mathrm{mg} / \mathrm{dl}$ ). After week 2 , the subjects were fed a normal diet for $3 \mathrm{wk}$. During weeks 6 and 7 , the diet restriction and treatment cycle that were carried out in weeks 1 and 2 were repeated using the alternate treatment. The sequence of the GH/IGF-I and IGF-I treatments was randomized among the subjects.

Measurements. Body weight was recorded daily. 24-h urinary excretion of creatinine, urea nitrogen, and potassium were measured by autoanalyzer (Hitachi 717; Boehringer Mannheim Diagnostic Lab Systems, Indianapolis, IN, and Synchron CX3; Beckman Instruments, Inc., Fullerton, CA). Urine collections for which the creatinine varied by $>15 \%$ from the mean for an individual subject were omitted from the analysis ( 2 of 154 collections were omitted ). Daily nitrogen balance was calculated by subtracting the sum of the urinary urea nitrogen excretion and estimated stool and integument losses $(245 \mathrm{mmol})$ from the daily nitrogen intake (16). The nitrogen content of food not eaten was subtracted from the total intake. Capillary blood glucose was measured during the IGF-I infusions at $\sim 2$-h intervals at the bedside (Chemstrip BG, Accucheck II; Boehringer-Mannheim). Serum potassium, glucose, urea nitrogen, and creatinine were measured by autoanalyzer (Synchron CX3; Beckman Instruments, Inc.).

IGF-I concentrations were measured by RIA after separating IGF-I from IGF binding proteins using octadecasilyl-silica cartridges (C-18 Sep-Paks; Waters Associates, Millipore Corp., Milford, MA) (17). The results were expressed as $\mu \mathrm{g} /$ liter after correcting for losses during extraction. The intra- and interassay coefficients of variation for this assay were $6.1 \%$. Serum insulin was measured by RIA (18), and serum C-peptide was measured with a RIA kit (Incstar, Stillwater, MN). The lower limit of detection for the insulin assay is $18 \mathrm{pmol} /$ liter, and for the C-peptide assay it is $92 \mathrm{pmol} /$ liter. IGFBP- 1 and 2 were assayed by disequilibrium RIA $(19,20)$. The lower limits of detection for the
IGFBP- 1 and 2 assays are 2 and $0.2 \mathrm{ng} / \mathrm{ml}$, respectively. The intra- and interassay coefficients of variation for IGFBP-1 were 9 and 15\%, respectively. The intra- and interassay coefficients of variation for IGFBP-2 were 6 and 10\%, respectively. IGFBP3 concentrations were measured by RIA using recombinant human IGFBP3 (gift from Genentech, Inc.) as a standard. The antiserum was prepared from rabbits immunized with human IGFBP3, as described previously for IGFBP1 (19). The antiserum bound $50 \%$ of the radiolabeled IGFBP 3 at a 1:20,000 dilution. ${ }^{125}$ I-IGFBP3 was prepared using a method described previously (19) and had a specific activity of $125 \mu \mathrm{Ci} / \mu \mathrm{g}$. The lower limit of detection is $1.0 \mathrm{ng} / \mathrm{ml}$, and the intra- and interassay coefficients of variation were 8 and $13 \%$, respectively. ALS concentrations were measured by RIA as previously described (21). The lower limit of detection is $0.5 \mu \mathrm{g} / \mathrm{ml}$.

All values were expressed as the mean $\pm \mathrm{SD}$, except for urinary potassium excretion, which was expressed as the mean $\pm \mathrm{SE}$. The data were analyzed for statistical significance by the paired $t$ test using the Bonferroni correction for repeated measurements. Unless otherwise stated, means and standard deviations in Results were calculated for the last 4 $\mathrm{d}$ of each diet and treatment week.

\section{Results}

The subjects lost $3.1 \pm 1.2$ (mean $\pm \mathrm{SD}$ ) and $2.7 \pm 0.6 \mathrm{~kg}$ during the week before IGF-I treatment and GH/IGF-I treatment, respectively $(P=\mathrm{NS})$. The mean nitrogen balance was $-139 \pm 48 \mathrm{mmol} / \mathrm{d}($ mean $\pm \mathrm{SD})$ during the IGF-I pretreatment week and $-140 \pm 50 \mathrm{mmol} / \mathrm{d}$ during the $\mathrm{GH} / \mathrm{IGF}-\mathrm{I}$ pretreatment week $(P=\mathrm{NS})$.

Anabolic effects. During the IGF-I treatment period, nitrogen balance improved from a pretreatment mean of $-139 \pm 48$ to $-31 \pm 29 \mathrm{mmol} / \mathrm{d}$ during the last $4 \mathrm{~d}$ of treatment $(P$ $<0.001$; Fig. 1). GH/IGF-I treatment, however, induced entry into positive nitrogen balance, from a pretreatment mean of $-140 \pm 50$ to $+122 \pm 43 \mathrm{mmol} / \mathrm{d}$ during the last $4 \mathrm{~d}$ of treatment

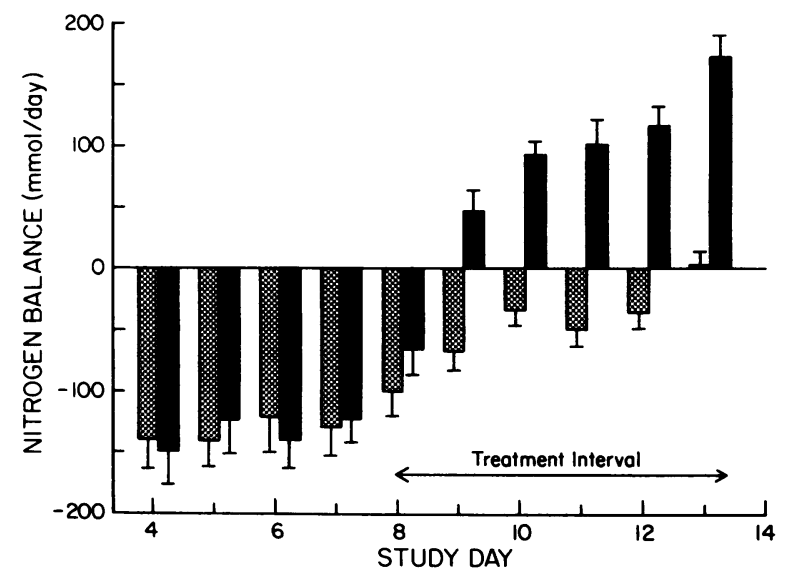

Figure 1. Changes in nitrogen balance in response to infusion of IGF-I $(\mathbb{*})$ or combined treatment with GH and IGF-I ( $\square$ ). IGF-I was given by continuous infusion ( $12 \mu \mathrm{g} / \mathrm{kg}$ IBW per $\mathrm{h}$ ) for $16 \mathrm{~h}$ on days $8-12$ between the hours of 1600 and 0800 . On day 13 , the infusion was given between 0800 and 2400 hours. GH was given by subcutaneous injection $(0.05 \mathrm{mg} / \mathrm{kg} \mathrm{IBW})$ at $1600 \mathrm{~h}$ on days $8-12$ and at 0800 on day 13. Daily nitrogen balance was calculated by subtracting the sum of the 24-h urinary urea nitrogen excretion and the estimate of stool and integument losses $(245 \mathrm{mmol})$ from the daily nitrogen intake. The results are expressed as the mean \pm SD for seven subjects for the last $4 \mathrm{~d}$ of each diet and treatment week. The differences in nitrogen balance between treatment groups were significant $(P<0.01)$ on days 9-13. 
$(P<0.001)$. The improvement produced by the combination was significantly greater than that produced by IGF-I alone ( $P$ $<0.001$ ).

The improvements in nitrogen balance were accompanied by decreases in serum urea nitrogen. From a pretreatment concentration of $5.54 \pm 0.93 \mathrm{mmol} /$ liter (mean \pm SD), IGF-I treatment decreased serum urea nitrogen to $2.35 \pm 0.44 \mathrm{mmol} /$ liter $(P<0.001)$. From a pretreatment mean of $5.63 \pm 1.08 \mathrm{mmol} /$ liter, GH/IGF-I treatment decreased serum urea nitrogen to $1.35 \pm 0.33 \mathrm{mmol} /$ liter $(P<0.001)$. The mean value during GH/IGF-I was significantly lower than that during IGF-I alone $(P<0.001)$.

In keeping with changes in nitrogen balance, the GH/IGF-I combination reduced urinary potassium excretion (pretreatment $67 \pm 7 \mathrm{mmol} / \mathrm{d}$ vs. on treatment $33 \pm 3 \mathrm{mmol} / \mathrm{d}$, mean \pm SE; $P<0.001$ ) (Fig. 2). With IGF-I alone, however, urinary potassium excretion did not change (pretreatment mean of $61 \pm 5 \mathrm{mmol} /$ day vs. on treatment mean of $61 \pm 5$ $\mathrm{mmol} / \mathrm{d})$. Serum potassium decreased on IGF-I alone, from a pretreatment concentration of $4.2 \pm 0.2(\mathrm{mean} \pm \mathrm{SD})$ to $3.8 \pm 0.3$ $\mathrm{mmol} /$ liter $(P<0.001)$, and from $4.1 \pm 0.2$ to $3.6 \pm 0.2 \mathrm{mmol} /$ liter on GH/IGF-I $(P<0.001)$. The difference in serum potassium between the treatment groups was significant $(P$ $=0.002$ ).

Effects on IGF-I concentration. From a pretreatment concentration of $255 \pm 94 \mu \mathrm{g} /$ liter (mean $\pm \mathrm{SD}$ ), serum IGF-I increased to $1,092 \pm 503 \mu \mathrm{g} /$ liter during IGF-I treatment $(P$ $<0.001$ ) (Fig. 3). GH/IGF-I treatment produced an even greater elevation in IGF-I concentration, from $273 \pm 106$ to $1,854 \pm 708 \mu \mathrm{g} /$ liter $(P<0.001)$. During the 8 -h interval in which IGF-I was not infused (0800-1600) on day 11, serum IGF-I concentrations declined in both treatment groups $(1,114 \pm 483$ to $769 \pm 633 \mu \mathrm{g} /$ liter on IGF-I treatment and $1,841 \pm 637$ to $1,568 \pm 622 \mu \mathrm{g} /$ liter on GH/IGF-I treatment). When the IGF-I infusion was resumed at $1600 \mathrm{~h}$, steady state IGF-I concentrations were achieved in both treatment groups within $4 \mathrm{~h}$.

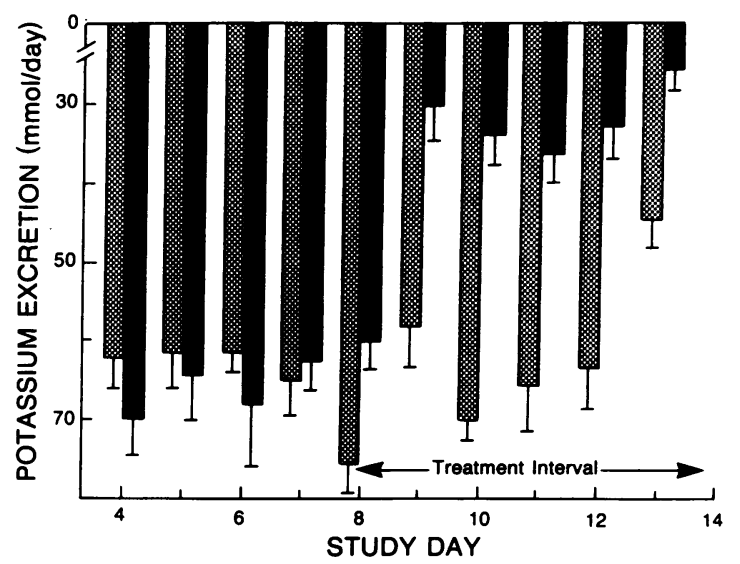

Figure 2. Changes in urinary potassium excretion in response to infusion of IGF-I ( $\otimes$ ) or combined treatment with GH and IGF-I ( $\square$ ). IGF-I and GH were administered as indicated in the legend in Fig. 1. Daily urinary potassium excretion was measured from 24-h urine collections. The results are expressed as the mean $\pm \mathrm{SE}$ for seven subjects for the last $4 \mathrm{~d}$ of each diet and treatment week. The differences in urinary potassium excretion between treatment groups were significant $(P<0.01)$ on days $9-13$.

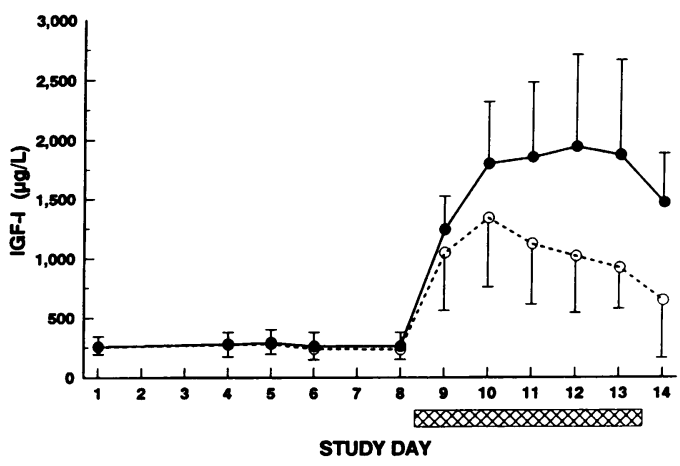

Figure 3. Changes in serum IGF-I concentration in response to GH/

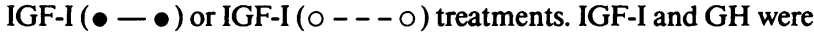
administered as indicated in the legend in Fig. 1. Blood samples for measurement of IGF-I by RIA were collected at $0700,1 \mathrm{~h}$ before the end of each IGF-I infusion on days 9-13 and $7 \mathrm{~h}$ after the end of the infusion on day 14 . The results are expressed as the mean \pm SD for seven subjects. The differences in IGF-I concentrations between treatment groups were significant $(P<0.01)$ on days $11-14$. Treatment interval (㖥).

Effects on carbohydrate metabolism. Capillary blood glucose concentrations measured every $2 \mathrm{~h}$ during IGF-I infusions were consistently higher on GH/IGF-I $(4.3 \pm 1.0 \mathrm{mmol} /$ liter; mean \pm SD) compared to IGF-I alone $(3.8 \pm 0.8 \mathrm{mmol} /$ liter $)(P$ $<0.001$; Fig. 4$)$. Furthermore, $17.3 \%$ of values fell below 3.05 $\mathrm{mmol} /$ liter $(55 \mathrm{mg} / \mathrm{dl})$ during IGF-I treatment, whereas only $8.1 \%$ were low during GH/IGF-I treatment. Euglycemia was maintained better on the GH/IGF-I regimen compared to IGF-I treatment. This was apparent even though the IGF-I infusion had to be stopped or slowed several times during treatment with IGF-I alone, whereas the GH/IGF-I subjects continued to receive a constant rate of infusion. A total of five episodes of symptomatic hypoglycemia (tremulousness, lightheadedness, diaphoresis, and headache) occurred in four subjects on IGF-I treatment compared to two episodes in two subjects on GH/IGF-I treatment. Both episodes on GH/IGF-I occurred during the first day of treatment. Morning $(0700 \mathrm{~h})$ serum glucose concentrations ( $1-2 \mathrm{~h}$ after $1.7 \mathrm{kcal} / \mathrm{kg}$ of carbohydrate) were also higher during GH/IGF-I treatment $(5.7 \pm 0.7 \mathrm{mmol} /$ liter; mean $\pm \mathrm{SD})$ than during IGF-I alone $(4.3 \pm 1.1 \mathrm{mmol} /$ liter; $P<0.001)$.

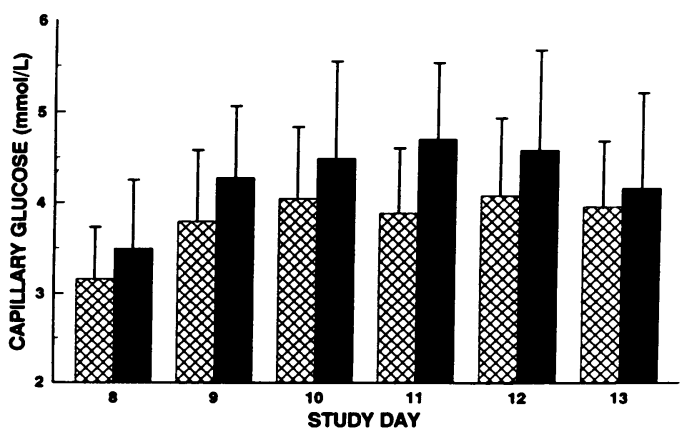

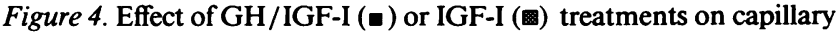
glucose. Capillary glucose was measured every $2 \mathrm{~h}$ during the IGF-I infusion by a reflectance meter (Accucheck II; Boehringer Mannheim). Each bar represents the mean \pm SD of 42 measurements. The differences in capillary glucoses between treatment groups were significant $(P<0.01)$ on days $9-12$. 


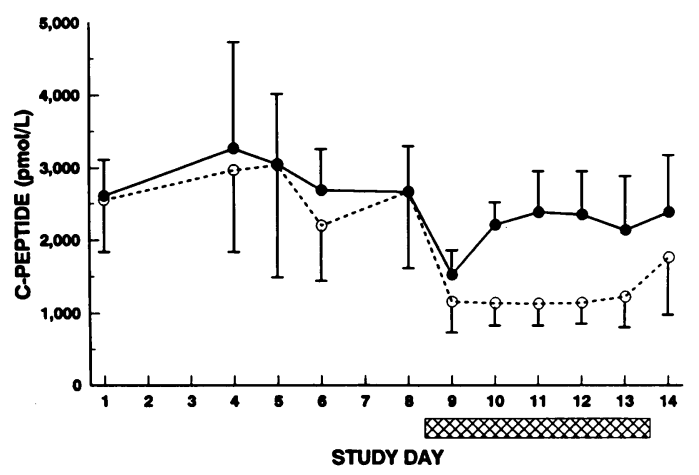

Figure 5. Effect of GH/IGF-I $(\bullet-\bullet)$ or IGF-I $(0---0)$ treatments on C-peptide concentrations. Blood samples for C-peptide measurement by RIA were collected at $0700,1 \mathrm{~h}$ before the end of each IGF-I infusion on days 9-13 and $7 \mathrm{~h}$ after the end of the infusion on day 14 . The results are the mean $\pm S D$ for seven subjects. The differences in C-peptide concentrations between treatment groups were significant on days 10-12. Treatment interval (四).

While receiving IGF-I alone, the pretreatment morning insulin concentration decreased from $49.8 \pm 35.2($ mean $\pm \mathrm{SD})$ to $16.6 \pm 12.7 \mathrm{pmol} /$ liter $(P<0.001)$, and the pretreatment $\mathrm{C}$ peptide concentration fell from $2,721 \pm 1,228($ mean \pm SD) to $1,165 \pm 341 \mathrm{pmol} /$ liter $(P<0.001$, Fig. 5$)$. During GH/IGF-I, insulin decreased from a pretreatment mean of $44.9 \pm 26.8$ to $33.4 \pm 16.7 \mathrm{pmol} /$ liter $(P=0.04)$, and C-peptide declined from a pretreatment mean of $2,923 \pm 1,039$ to $2,280 \pm 612 \mathrm{pmol} /$ liter $(P=0.02$; Fig. 5). The decreases in insulin and C-peptide concentrations were significantly greater during IGF-I treatment than during GH/IGF-I $(P<0.001$ for $\mathrm{C}$-peptide and $P$ $=0.001$ for insulin .

Effects on IGFBPs and the ALS of the 150-kD binding protein complex. GH/IGF-I increased IGFBP3 from 4.54 \pm 1.20 (mean \pm SD) to $6.40 \pm 1.70 \mu \mathrm{g} / \mathrm{ml}(P<0.01)$, whereas IGF-I suppressed IGFBP3 from a pretreatment mean of $4.53 \pm 1.10$ to $2.85 \pm 1.22 \mu \mathrm{g} / \mathrm{ml}(P<0.01$; Fig. $6 A)$. The difference in IGFBP 3 concentration produced by each treatment was significant $(P<0.001)$. IGFBP2 concentration increased on IGF-I from $242 \pm 153($ mean \pm SD) to $497 \pm 268 \mathrm{ng} / \mathrm{ml}(P=0.002)$, whereas GH/IGF-I treatment resulted in no change in the IGFBP2 concentration. IGF-I alone increased IGFBP1 from $68 \pm 20($ mean \pm SD) to $98 \pm 25 \mathrm{ng} / \mathrm{ml}(P<0.001)$, whereas GH/IGF-I suppressed IGFBP1 ( $76 \pm 20$ pretreatment to $65 \pm 8$ $\mathrm{ng} / \mathrm{ml} ; P=0.02)$. The difference between the two treatment groups was significant $(P<0.001)$.

IGF-I alone suppressed ALS from a pretreatment concentration of $33 \pm 12($ mean \pm SD $)$ to $19 \pm 10 \mu \mathrm{g} / \mathrm{ml}(P=0.001$; Fig. $6 \mathrm{~B}$ ), whereas GH/IGF-I maintained ALS concentration $(32 \pm 10 \mu \mathrm{g} / \mathrm{ml}$ pretreatment to $40 \pm 13 \mu \mathrm{g} / \mathrm{ml} ; P=0.07)$. The difference in ALS concentration produced by each treatment was significant $(P<0.001)$.

Side effects. No significant adverse effects were observed during either the IGF-I or GH/IGF-I treatments. Six of the seven subjects reported discomfort over the area of the parotid glands during both treatments. Only one subject developed palpable enlargement of these glands, however, the serum amylase remained normal. Six subjects during GH/IGF-I treatment and four subjects during IGF-I treatment developed periorbital edema. One subject developed pitting edema in the extremities during GH/IGF-I treatment. During the treatment week, the
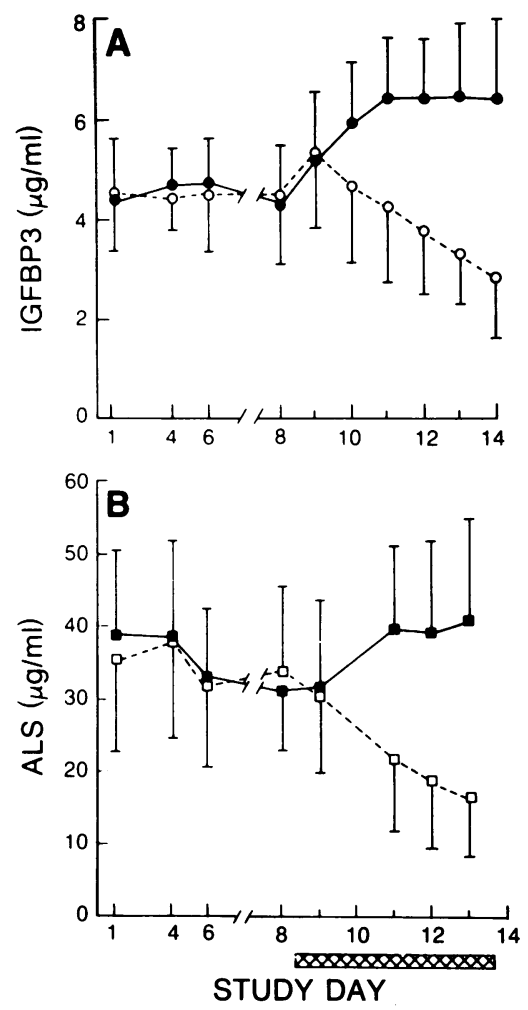

Figure 6. Effect of GH/ IGF-I or IGF-I treatments on $(A)$ IGFBP3 and $(B)$ ALS concentrations. Blood samples were obtained at 0700 , $1 \mathrm{~h}$ before the end of each IGF-I infusion on days $9-13$ and $7 \mathrm{~h}$ after the end of the infusion on day 14. IGFBP3 and ALS concentrations were determined by RIA. The results are expressed as the mean \pm SD for seven subjects for the last $3 \mathrm{~d}$ of each diet and treatment week. The differences in IGFBP3 and ALS between treatment groups were significant $(P<0.01)$ on days $11-$ 14 and days $11-13$, respectively. IGFBP3:

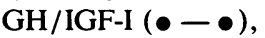
IGF-I: $(0---0)$; ALS: GH/IGF-I ( - -), IGF-I (口- - - ); treatment interval ( $\square)$.

subjects gained $0.5 \pm 0.9 \mathrm{~kg}$ (mean $\pm \mathrm{SD})$ on IGF-I alone and $2.1 \pm 1.7 \mathrm{~kg}$ on GH/IGF-I. The proportion of weight gain attributable to fluid retention or nitrogen accretion could not be determined because sodium balance was not analyzed. Most of the edema and all parotid tenderness resolved in every subject within $3 \mathrm{~d}$ after discontinuing treatment.

\section{Discussion}

Our results show that the combination of GH and IGF-I treatment in calorically restricted humans is substantially more anabolic than either GH or IGF-I alone. The nitrogen retention induced by the GH/IGF-I combination was 2.4-fold greater than IGF-I alone ( $56 \pm 9$ vs. $23 \pm 7 \%$ ). Compared to results from our previous study (14), in which the effects of GH and IGF-I were analyzed individually, the GH/IGF-I combination caused 2.1-fold greater nitrogen retention than GH alone ( $56 \pm 9$ vs. $26 \pm 8 \%$ ). We consider the present experiments comparable to our previous study (14) because subject characteristics, study design, and GH and IGF-I doses were identical to the present study, and the responses in the each of the two studies to IGF-I alone were nearly identical.

The mean increase in nitrogen retention of $260 \mathrm{mmol} / \mathrm{d}$ caused by GH/IGF-I treatment is greater than that achieved in any previous trial using GH alone in catabolic subjects. Ward et al. treated postoperative gastrointestinal patients with $\mathrm{GH}$ $(0.1 \mathrm{mg} / \mathrm{kg}$ per d) for $6 \mathrm{~d}$ and observed a mean increase in nitrogen retention of $127 \mathrm{mmol} / \mathrm{d}$ compared to placebo (4). In patients with chronic obstructive pulmonary disease, $\mathrm{GH}(0.05$ $\mathrm{mg} / \mathrm{kg}$ per d) caused a mean increase in nitrogen retention of $158 \mathrm{mmol} / \mathrm{d}$ compared to control (6). When obese subjects were calorically restricted ( $12 \mathrm{kcal} / \mathrm{kg} \mathrm{IBW}$ per d) and treated with $\mathrm{GH}(0.1 \mathrm{mg} / \mathrm{kg} \mathrm{IBW}$ every other day $)$ for $5 \mathrm{wk}$, the mean 
nitrogen retention improved by $128 \mathrm{mmol} / \mathrm{d}$ compared to placebo (22). Marcus et al. treated normal elderly subjects with $\mathrm{GH}(0.06 \mathrm{mg} / \mathrm{kg}$ per $\mathrm{d})$ for $7 \mathrm{~d}$ and observed a mean increase in nitrogen retention of $193 \mathrm{mmol} / \mathrm{d}$ (23). The magnitude of nitrogen conservation in each of these trials of $\mathrm{GH}$ falls short of that which we observed with GH plus IGF-I.

Although a GH dose-response was observed in the study in elderly subjects (23), it is doubtful that higher doses of $\mathrm{GH}$ would have produced increases in nitrogen retention in catabolic patients that were equal to that caused by GH plus IGF-I. In obese, diet-restricted subjects, doubling the standard $\mathrm{GH}$ treatment dose to $0.1 \mathrm{mg} / \mathrm{kg}$ IBW per d caused only a $10 \%$ improvement in nitrogen retention $(22,24)$. Manson and Wilmore ( 8 ) observed a mean increase in nitrogen retention of 179 $\mathrm{mmol} / \mathrm{d}$ in calorically restricted normal volunteers given high dose $\mathrm{GH}(0.14 \mathrm{mg} / \mathrm{kg}$ per d). More recently, Zeigler et al. reported an increase of $201 \mathrm{mmol} / \mathrm{d}$ in subjects receiving a high dose of $\mathrm{GH}(0.18 \mathrm{mg} / \mathrm{kg}$ per $\mathrm{d})$ along with hyperalimentation therapy (25).

During catabolism a significant portion of the nitrogen excreted is derived from increased turnover of visceral protein. Since $83 \%$ of the total body potassium is contained in muscle and connective tissue compartments $(26,27)$, measurement of potassium balance is considered to be a good index of protein accretion in these compartments. We observed a marked decline in urinary potassium excretion on GH/IGF-I treatment suggesting that most nitrogen accretion occurred in muscle and nonvisceral protein. The failure of potassium excretion to decline during treatment with IGF-I alone might be the result of a less pronounced anabolic effect of IGF-I on muscle and nonvisceral protein accretion or a direct enhancement of renal potassium secretion that counterbalanced a positive effect of IGFI on potassium accretion.

In a previous study (28), IGF-I infusions of $32 \mu \mathrm{g} / \mathrm{kg}$ per h in healthy volunteers on a normal diet were reported to cause hypoglycemia. However, when the IGF-I dose was lowered to $20 \mu \mathrm{g} / \mathrm{kg}$ per h, hypoglycemia did not occur (28). In contrast, we previously showed that an IGF-I infusion of only $12 \mu \mathrm{g} / \mathrm{kg}$ per $h$ in calorically restricted humans caused hypoglycemia despite the fact that insulin levels were suppressed three- to fourfold (14). These observations suggest that catabolic subjects, who may have decreased caloric intake or increased substrate utilization, might be more sensitive than normal subjects to the hypoglycemic effects of IGF-I. Addition of $\mathrm{GH}$ to the treatment regimen attenuated the hypoglycemia despite the fact that the GH/IGF-I combination produced higher serum IGF-I concentrations than those on IGF-I treatment alone. This protective effect of $\mathrm{GH}$ may have resulted from the higher IGFBP 3 concentrations, sequestering IGF-I and preventing its rapid efflux from the circulation (29). Another explanation might be that GH's tendency to cause insulin resistance counteracts the hypoglycemic effect of IGF-I (11). Conversely, the hyperglycemia and hyperinsulinemia associated with $\mathrm{GH}$ treatment alone were prevented by the combination treatment, suggesting that IGF-I counteracts $\mathrm{GH}$-induced glucose intolerance (14).

Several mechanisms might explain the greater anabolic effect of the GH/IGF-I combination. First, GH/IGF-I treatment caused markedly higher serum IGF-I concentrations than IGF-I alone, possibly producing higher concentrations of IGF-I in tissues. Second, the addition of GH to IGF-I treatment reversed the insulin suppressive effect of IGF-I. These higher insulin concentrations could enhance the anabolic effect of IGF-I, since insulin inhibits proteolysis $(30,31)$. Third, GH and IGF-I may each affect protein balance by different mechanisms. For example, $\mathrm{GH}$ administered to normal volunteers causes an increase in protein synthesis but does not significantly inhibit proteolysis (5). In contrast, the predominant mechanism that mediates the response to IGF-I infusion appears to be inhibition of proteolysis (30). Fourth, the induction of IGFBP3 and ALS by the GH/IGF-I combination might account for a more stable IGF-I pool, which in turn might provide more anabolic effect. IGFBP3 is the major carrier protein of IGF-I in serum (32), and its association with IGF-I and ALS in a $150-\mathrm{kD}$ ternary complex (33) increases the half-life of IGF-I by more than 50 -fold (34). In humans and hypophysectomized rats, GH induces IGFBP3 and ALS (35-37). Formation of the ternary complex in response to $\mathrm{GH}$ is likely to have facilitated stabilization of the IGF-I pool in the GH/IGF-I treatment group. In contrast, infusion of only IGF-I lowered IGFBP-3 and ALS, and is thereby likely to have caused a decrease in stability of IGF-I in the circulation. This effect might have resulted from suppression of GH secretion by IGF-I, although GH was not measured in this study. Stabilization of IGF-I during GH/IGF-I treatment may have allowed peripheral tissues to be exposed continuously to higher concentrations of IGF-I.

Insulin and IGF-I have qualitatively similar metabolic and anabolic effects in that both decrease serum glucose and inhibit proteolysis $(30,38)$. Since the mechanism of IGF-I action is unknown, we cannot rule out the possibility that the anabolic effects of IGF-I observed in this study might be mediated by an insulin-like mechanism.

Although treatment with GH/IGF-I and IGF-I alone caused fluid retention and parotid tenderness, these side effects were transient and well-tolerated. The fluid retention can probably be explained by the fact that both GH and IGF-I decrease renal sodium excretion and increase water reabsorption (13, $23,39,40)$. Parotid tenderness with intravenous IGF-I administration was observed in our previous study (14) and has been described by other investigators (Lowry, S. F., personal communication ), however the cause of this effect is unknown. The hypoglycemia associated with the GH/IGF-I combination occurred mostly on the first day of treatment and may have been prevented entirely by administration of $\mathrm{GH}$ before initiating the IGF-I infusion. This strategy would be based on the observation that $\mathrm{C}$-peptide concentrations initially declined and then recovered on the second day of GH/IGF-I treatment, suggesting that the insulin resistance induced by $\mathrm{GH}$ was delayed by $24-48 \mathrm{~h}$.

Our results in this diet restriction, catabolic model suggest that the combination of GH/IGF-I could have important applications in diseases associated with catabolism. Since a variety of illnesses lead to either suppression of appetite or reduced nutrient absorption, therapy with GH and IGF-I could shorten the convalescent phase. Patients with extensive surface burns or sepsis have been reported to be refractory to $\mathrm{GH}(9,10)$. The combination of GH and IGF-I could potentially be more effective in such patients. Maintenance of normal glucose tolerance by the GH/IGF-I combination suggests that treatment with both of these agents might be safer than IGF-I alone in patients who are predisposed to hypoglycemia because of reduced caloric intake. Finally, the hyperglycemia that sometimes develops in response to $\mathrm{GH}$ administration may be ame- 
liorated by the combination therapy since the IGF-I dose could be used to adjust blood glucose. The challenge for the future is to determine whether this combination has efficacy in disease states that are known to result in significant catabolism.

\section{Acknowledgments}

The authors acknowledge the assistance of Andrew Perlman, M.D. Ph.D., and Neil Gesundheit, M.D., of Genentech, Inc., who supplied the IGF-I and GH and provided valuable advice, and the technical assistance of Ms. Eyvonne Bruton.

The General Clinical Research Center of the University of North Carolina is supported by grant RR 00046 of the General Clinical Research Centers Program of the Division of Research Services of the National Institutes of Health. This work was supported by National Institutes of Health grant HD 26871 and by a gift from Genetech, Inc.

\section{References}

1. Waterlow, J. C., M. Golden, and D. Picou. 1977. The measurement of rates of protein turnover, synthesis, and breakdown in man and the effects of nutritional status and surgical injury. Am. J. Clin. Nutr. 30:1333-1339.

2. Shaw, J. H. S., M. Wildbore, and R. R. Wolfe. 1986. Whole body protein kinetics in severely septic patients: the response to glucose infusion and total parenteral nutrition. Ann. Surg. 205:288-294.

3. Streat, S. J., A. H. Beddoe, and L. H. Graham. 1987. Aggressive nutritional support does not prevent protein loss despite fat gain in septic intensive care patients. J. Trauma. 27:262-266.

4. Ward, H. C., D. Halliday, and A. J. W. Sim. 1987. Protein and energy metabolism with biosynthetic human growth hormone after gastrointestinal surgery. Ann. Surg. 206:56-61.

5. Horber, F. F., and M. W. Haymond. 1990. Human growth hormone prevents protein catabolic side effects of prednisone in humans. J. Clin. Invest 86:265-272.

6. Pape, G. S., M. Freidman, L. E. Underwood, and D. R. Clemmons. 1991. The effect of growth hormone on weight gain and pulmonary function in patients with chronic obstructive lung disease. Chest. 99:1495-1500.

7. Snyder, D. K., D. R. Clemmons, and L. E. Underwood. 1988. Treatment of obese, diet-restricted subjects with growth hormone for 11 weeks: effects on anabolism, lipolysis and body composition. J. Clin. Endocrinol. Metab. 67:54-61.

8. Manson, J. McK., and D. W. Wilmore. 1986. Positive nitrogen balance with human growth hormone and hypocaloric intravenous feeding. Surgery (St. Louis). 100:188-197.

9. Dahn, M. S., M. P. Lange, and L. A. Jacobs. 1988. Insulin-like growth factor I production is inhibited in human sepsis. Arch. Surg. 123:1409-1414.

10. Belcher, H. J. C. R., D. Mercer, K. C. Judkins, S. Shalaby, S. Wise, V. Marks, and N. S. B. Tanner. 1989. Biosynthetic growth hormone in burned patients: a pilot study. Burns. 15:99-107.

11. Sherwin, R. S., G. A. Shulman, R. Hendler, A. B. Walesky, A. Belous, and W. Tamborlane. 1983. Effect of growth hormone on oral glucose tolerance and circulating metabolic fuels in man. Diabetologia. 24:155-161.

12. Guler, H. P., J. Zapf, E. Scheiwiller, and E. R. Froesch. 1988. Recombinant human insulin-like growth factor-I stimulates growth and has distinct effects on organ size in hypophysectomized rats. Proc. Natl. Acad. Sci. USA. 85:48894893.

13. Walker, J. L., M. G. Ginalska-Malinowska, T. E. Romer, J. B. Pucilowska, and L. E. Underwood. 1991. Effects of the infusion of insulin-like growth-factor-I in a child with growth hormone insensitivity syndrome (Laron dwarfism). $N$. Engl. J. Med. 324:1483-1488.

14. Clemmons, D. R., A. Smith-Banks, and L. E. Underwood. 1992. Reversal of diet-induced catabolism by infusion of recombinant insulin-like growth factor (IGF-I) in humans. J. Clin. Endocrinol. Metab. 75:234-238.

15. Metropolitan Life Insurance Co. New Weight Standards for Men and Women. 1983. Stal. Bul. Metropol. Life Insurance Co. 64:2-9.

16. USDA Handbook No. 8. 1976. United States Department of Agriculture, Washington, DC.

17. Davenport, M. L., M. E. Svoboda, K. L. Koerber, J. J. Van Wyk, D. R. Clemmons, and L. E. Underwood. 1988. Serum concentrations of insulin-like growth factor II are not changed by short term fasting and refeeding. J. Clin. Endocrinol. Metab. 67:1231-1236.

18. Voina, S. J., L. E. Underwood, and J. J. Van Wyk. 1971. Failure of leucine, arginine and epinephrine to alter plasma insulin levels in vitro. Horm. Metab. Res. 3:127-128.

19. Busby, W. H., D. K. Snyder, and D. R. Clemmons. 1988. Radioimmunoassay of a 26,000 dalton plasma insulin-like growth factor binding protein: control by nutritional variables. J. Clin. Endocrinol. Metab. 67:1225-1230.

20. Clemmons, D. R., W. H. Busby, and D. K. Snyder. 1991. Variables controlling the secretion of insulin-like growth factor binding protein-2 in normal human subjects. J. Clin. Endocrinol. Metab. 73:727-733.

21. Baxter, R. C. 1990. Circulating levels and molecular distribution of the acid-labile $(\alpha)$ subunit of the high molecular weight insulin-like growth factorbinding protein complex. J. Clin. Endocrinol. Metab. 70:1347-1353.

22. Snyder, D. K., D. R. Clemmons, and L. E. Underwood. 1989. Dietary carbohydrate content determines responsiveness to growth hormone in energyrestricted humans. J. Clin. Endocrinol. Metab. 69:745-752.

23. Marcus, R., G. Butterfield, L. Holloway, L. Gilliland, D. J. Baylink, R. L. Hintz, and B. M. Sherman. 1990. Effects of short term administration of recombinant human growth hormone to elderly people. J. Clin. Endocrinol. Metab. 70:519-527.

24. Snyder, D. K., L. E. Underwood, and D. R. Clemmons. 1990. Anabolic effects of growth hormone in obese diet-restricted subjects are dose dependent. Am. J. Clin. Nutr. 52:431-437.

25. Zeigler, T. R., J. L. Rombeau, L. S. Young, Y. Fong, M. Marano, S. F. Lowry, and D. W. Wilmore. 1992. Recombinant human growth hormone enhances the metabolic efficacy of parenteral nutrition: a double-blind, randomized controlled study. J. Clin. Endocrinol. Metab. 74:865-873.

26. Stein, P. T. 1982. Nutrition and protein turnover: a review. J. Parenter. Enternal Nutr. 6:444-454.

27. Cohn, S. H., D. Vartsky, S. Yasumra, A. Sawitsky, I. Zanzi, A. Vaswani, and K. J. Ellis. 1980. Compartmental body composition based on total-body nitrogen, potassium, and calcium. Am. J. Physiol. 239:E524-530.

28. Guler, H. P., C. Schmid, J. Zapf, and E. R. Froesch. 1989. Effect of recombinant human insulin-like growth factor-I on insulin secretion and renal function in normal human subjects. Proc. Natl. Acad. Sci. USA. 86:2868-2872.

29. Binoux, M., and P. Hossenlopp. 1988. Insulin-like growth factor (IGF) and IGF-binding proteins: comparison of human serum and lymph. J. Clin. Endocrinol. Metab. 67:509-514.

30. Jacob, R., E. Barrett, G. Plewe, K. D. Fagin, and R. J. Sherwin. 1989. Acute effects of insulin-like growth factor I on glucose and amino acid metabolism in the awake fasted rat. J. Clin. Invest. 83:1717-1723.

31. Fukagawa, N. K., K. L. Minaker, J. W. Rowe, M. N. Goodman, D. E. Matthews, D. M. Bier, and V. R. Young. 1985. Insulin-mediated reduction of whole body protein breakdown. Dose-response effects on leucine metabolism in postabsorptive men. J. Clin. Invest. 76:2306-2311.

32. Daughaday, W. H., A. P. Ward, A. C. Goldberg, B. Trivedi, and M. Kapadia. 1982. Characterization of somatomedin binding in human serum by ultracentrifugation and gel filtration. J. Clin. Endocrinol. Metab. 55:916-921.

33. Baxter, R. C., and J. L. Martin. 1989. Structure of the $M_{\mathrm{r}} 140,000$ growth hormone-dependent insulin-like growth factor binding protein complex: determination by reconstitution and affinity labeling. Proc. Natl. Acad. Sci. USA. 86:6898-6902.

34. Guler, H. P., J. Zapf, C. Schmid, and E. R. Froesch. 1989. Insulin-like growth factors $I$ and II in healthy man: estimations of half-lives and production rates. Acta Endocrinol. (Copenh.) 121:753-758.

35. Zapf, J., C. Schmid, H. P. Guler, M. Waldvogel, C. Hauri, E. Futo, P. Hossenlopp, M. Binoux, and E. R. Froesch. 1990. Regulation of binding proteins for insulin-like growth factors (IGF) in humans. Increased expression of IGF binding protein 2 during IGF-I treatment of healthy adults and in patients with extrapancreatic tumor hypoglycemia. J. Clin. Invest. 86:952-961.

36. Clemmons, D. R., J. P. Thissen, M. Maes, J. M. Ketelslegers, and L. E. Underwood. 1989. Insulin-like growth factor-I (IGF-I) infusion into hypophysectomized or protein-deprived rats induces specific IGF-binding proteins in serum. Endocrinology. 125:2967-2972.

37. Zapf, J., C. Hauri, M. Wadlvogel, E. Futo, H. Hasler, K. Binz, H. P. Guler, C. Schmid, and E. R. Froesch. 1989. Recombinant human insulin-like growth factor I induces its own specific carrier protein in hypophysectomized and diabetic rats. Proc. Natl. Acad. Sci. USA. 86:3813-3817.

38. Guler, H. P., J. Zapf, and E. R. Froesch. 1987. Short-term metabolic effects of recombinant human insulin-like growth factor I in healthy adults. $N$. Engl. J. Med. 317:137-140.

39. Guler, H. P., K. U. Eckhardt, J. Zapf, C. Bauer, and E. R. Froesch. 1989. Insulin-like growth factor I increases glomerular filtration rate and renal plasma flow in man. Acta Endocrinol. 121:101-106.

40. Ho, K. Y., and A. J. Weissberger. 1990. The antinatriuretic action of biosynthetic human growth hormone in man involves activation of the renin-angiotensin system. Metabolism. 39:133-137. 